\title{
Fruit quality and storability of peach fruits (Prunus persica) in response to hot water treatments
}

Muhammad Sajid ${ }^{1}$, Irfan Ullah ${ }^{1 *}$, Islam Zeb ${ }^{1}$, Abdur Rab ${ }^{1}$, Zahoor Ahmad $^{1}$, Farida Bibi ${ }^{1}$, Mati Ullah Khan ${ }^{2}$, Muzammil Hussain ${ }^{1}$ and Sadiq Ullah $^{1}$

1. Department of Horticulture, The University of Agriculture Peshawar-Pakistan

2. Department of Plant Pathology, The University of Agriculture Peshawar-Pakistan

*Corresponding author's email: irfaan444@gmail.com

\section{Citation}

Muhammad Sajid, Irfan Ullah, Islam Zeb, Abdur Rab, Zahoor Ahmad, Farida Bibi, Mati Ullah Khan, Muzammil Hussain and Sadiq Ullah. Fruit quality and storability of peach fruits (Prunus persica) in response to hot water treatments. Pure and Applied Biology. Vol. 6, Issue 3, pp948-957. http://dx.doi.org/10.19045/bspab.2017.600100

\begin{tabular}{llll}
\hline \hline Received: 13/03/2017 & Revised: 15/07/2017 & Accepted: 26/07/2017 & Online First: 30/07/2017
\end{tabular}

\section{Abstract}

To evaluate the effect of hot water treatment on post-harvest of peach fruit cultivar 'Early Grand', an experiment was conducted in completely randomized design (CRD) having three repeats, at Horticultural laboratory, Department of Horticulture, The University of Agriculture Peshawar during 2013. Healthy and disease free peach fruits were dipped in hot water at various temperatures i.e. Control, 30, 40 and $50^{\circ} \mathrm{C}$ and its physico-chemical attributes were studied at each storage intervals of $0,10,20$ and 30 days. Results revealed significant differences for various studied variables of peach fruits at storage fruits dipped at $50^{\circ} \mathrm{C}$ water for 05 minutes showed maximum fruit juice $\mathrm{pH}$ (3.54), Total soluble solids $\left(11.49^{\circ} \mathrm{Brix}\right)$, Total sugars $(7.6 \%)$ and TSS:TA ratio (38.06) with minimum ascorbic acid content $\left(4.30 \mathrm{mg} .100 \mathrm{~g}^{-1}\right)$ and titratable acidity $(0.3 \%)$. The fruits treated with $40^{\circ} \mathrm{C}$ water were recorded with maximum fruit firmness $\left(1.73 \mathrm{~kg} . \mathrm{cm}^{-2}\right)$ with minimum weight loss $(2.57 \%)$ and disease incidence $(14.17 \%)$. The data referred to storage periods showed that the fruits stored for 30 days recorded maximum juice content (67.87\%), TSS $\left(9.86^{\circ}\right.$ Brix), fruit juice $\mathrm{pH}$ (3.91) and TSS:TA ratio (30.14). Interaction between hot water levels and storage durations revealed that peach fruits dipped in $50^{\circ} \mathrm{C}$ water and stored for 30 days showed minimum total sugars $(5.53 \%)$. It was concluded that hot water treatments at $40^{\circ} \mathrm{C}$ and storage period for 20 days induced best results on postharvest life of peach.

Keywords: Peach; Qualitative attributes; Water treatments; Shelf life

\section{Introduction}

Peach (Prunus persica) belongs to the family Rosaceae. It is the widely-grown fruit in temperate regions throughout the world. It was originated from China around 2000 B.C [1]. It is a healthy and delicious fruit used throughout the world. In Pakistan, it has got much importance in Khyber Pakhtunkhwa provinceand Northern areas. In Pakistan Peach is the $2^{\text {nd }}$ most important stone fruit after plums. It is a very important crop both for fresh and processing industry [2]. 
The postharvest quality of fresh commodities is very important for consumption and competition in the market. However, the maintenance of fruit quality demands constant vigilance because of their perishable nature, horticultural diversity, biochemistry, utility and consumer preferences [3]. Post-harvest treatments can enhance shelf life of the fruits and reduce losses during packaging. There are very severe and very limited registered products and methods practiced nowadays. Some of the physical methods practiced contain treatment of the fruits with high temperature. It controls pests, increase tolerance to chilling injuries, prevents pathogenic attacks, and extends post-harvest life by delaying fruit ripening [4]. Heat affects many fruit ripening processes, such as color, ethylene synthesis, respiration, fruit softening, cell wall metabolism and production of volatile compounds. Heat application changes the gene expression and protein synthesis, which causes inhibition of ethylene synthesis and action of cell wall degrading enzymes [5].Thus heat treatment applied before storage is a non-damaging physical method and an appropriate strategy for producers [6]. Various studies have been conducted on heat treatment for disease control and maintenance of quality. The fresh commodities subjected to heat application showed increase in protein levels and heat shock proteins transcripts [6]. Peach fruits dipped in water at the temperature of $46^{\circ} \mathrm{C}$ for 2 to $8 \mathrm{~min}$ were recorded with significantly enhanced disease resistance [7].

Considering the problems related to peach fruit quality, storability, and significance of the heat treatments, an experiment was carried out to study the influence of hot water treatment on storage and fruit quality of peach. The main objectives were to find out an optimum water temperature at which peaches can be treated and to determine the optimal storage duration for post-harvest life of peach fruit. Moreover, the integrated effect of hot water treatment and storage intervalsfor peaches was also investigated.

\section{Materials and methods}

The study was conducted at Horticultural laboratory, Department of Horticulture, The University of Agriculture Peshawar during June, 2013. Peach (Prunus persica) cv. Early Grand fruits were harvested at physiological mature stage from peach orchard, Horticulture Farm, The University of Agriculture, Peshawar. The experiment was laid out in completely randomized design (CRD) with two factors factorial arrangement in three replications. The experiment consists of hot water treatment (Control, $30^{\circ} \mathrm{C}, 40^{\circ} \mathrm{C}$ and $50^{\circ} \mathrm{C}$ ) and storage intervals ( 0 day, 10 days, 20 days and 30 days). The hot water treatments were given for a constant time period of 5 minutes.

Various parameters were recorded during the study. Percent disease incidence was recorded at each storage interval in each replication of treatments by visual observation of disease symptoms. It was presented as percentage of fruits showing the symptoms of disease after the respective storage period. Weight loss was observed as percent of the fruit weight lost against its original weight. For this purpose, initial and final weight of the fruits after storage was determined with the help of an electronic balance measuring weight in grams up to third decimal. Percent juice content was recorded such as calculating the amount of juice weight and then findings its percentage in the fruit weight. Total soluble solid content of fruits was determined at 10 days intervals of 30 days storage accordingly with a hand refractro-meter (Kernco, Insruments Co. Texas). Titratable acidity (TA) was determined by neutralization reaction as described in [8]. The juice $\mathrm{pH}$ during storage was determined with the help of electronic $\mathrm{pH}$ meter. Fruit firmness was determined at 
the end of each storage interval with the help of Wanger fruit firmness tester (model FT327). Reducing sugar and non-reducing sugar were determined by Lane Eynon method [8] to find out the total sugars. Ascorbic acid content was observed with the help of procedure given in [8]. The TSS to TA ratio was determined by the dividing the fruit total soluble solid value by fruit titratable acidity percent. The data recorded on these parameters were subjected to analysis of variance techniques (ANOVA) to observe the difference between treatments as well as their interactions. In case where the differences were significant, the means were further assessed for differences through least significant difference (LSD) test. Statistical computer software Statistix 8.1 was applied for computing both the ANOVA and LSD.

\section{Results and discussion}

\section{Fruit juice content}

Data recorded for fruit juice content is presented in Table 1. Data analysis indicated that hot water treatment had nonsignificant and storage duration and their interaction had significant effect on fruit juice content of peach. The mean table showed that maximum juice content $(70.78 \%)$ was observed in fruits left untreated while minimum $(67.64 \%)$ was observed in the fruits treated with water having $30^{\circ} \mathrm{C}$ temperatures. Regarding the storage durations, maximum juice content $(72.74 \%)$ was found in fruits stored for 30 days, while minimum $(65.17 \%)$ was recorded in fresh fruits. As referred to the interaction (Figure 1), maximum fruit juice content $(75.11 \%)$ was observed in the fruits dipped in $40^{\circ} \mathrm{C}$ water and stored for 30 days, while minimum was recorded in fresh peaches dipped in $30^{\circ} \mathrm{C}$.Reason for such results might be that the juice content increased with proceeding storage time. The fresh fruits had lower juice content whereas the stored have higher. These results are in harmony with Khan et al. [9] that the juice content in sweet oranges increased with increasing storage duration up to 45 days but in some treatments juice contents decreased after 60 days interval of storage.

Table 1. Fruit juice content, Percent weight loss, Percent disease incidence and fruit firmness of peach fruits as affected by hot water dipping and storage intervals

\begin{tabular}{|l|c|c|c|c|}
\hline $\begin{array}{l}\text { Hot water } \\
\text { dipping }\left({ }^{\circ} \mathbf{C}\right)\end{array}$ & Juice content $(\%)$ & $\begin{array}{c}\text { Weight loss } \\
(\%)\end{array}$ & $\begin{array}{c}\text { Disease incidence } \\
(\%)\end{array}$ & $\begin{array}{c}\text { Fruit firmness } \\
\left(\mathbf{k g ~ c m}^{\mathbf{\%}}\right)\end{array}$ \\
\hline Control & $70.78 \mathrm{a}$ & $5.04 \mathrm{~b}$ & $25.00 \mathrm{~b}$ & $1.30 \mathrm{bc}$ \\
\hline $30^{\circ} \mathrm{C}$ & $67.64 \mathrm{~b}$ & $2.94 \mathrm{c}$ & $20.00 \mathrm{bc}$ & $1.57 \mathrm{ab}$ \\
\hline $40^{\circ} \mathrm{C}$ & $68.07 \mathrm{ab}$ & $2.57 \mathrm{c}$ & $14.17 \mathrm{c}$ & $1.73 \mathrm{a}$ \\
\hline $50^{\circ} \mathrm{C}$ & $69.62 \mathrm{ab}$ & $7.63 \mathrm{a}$ & $49.17 \mathrm{a}$ & $1.29 \mathrm{c}$ \\
\hline $\begin{array}{l}\text { Storage } \\
\text { Duration (days) }\end{array}$ & $65.17 \mathrm{c}$ & $0.76 \mathrm{~d}$ & $0.00 \mathrm{~d}$ & $2.43 \mathrm{a}$ \\
\hline 0 & $68.16 \mathrm{~b}$ & $2.36 \mathrm{c}$ & $25.00 \mathrm{c}$ & $1.89 \mathrm{~b}$ \\
\hline 10 & $70.04 \mathrm{ab}$ & $4.63 \mathrm{~b}$ & $35.84 \mathrm{~b}$ & $1.16 \mathrm{c}$ \\
\hline 20 & $72.74 \mathrm{a}$ & $10.41 \mathrm{a}$ & $47.50 \mathrm{a}$ & $0.41 \mathrm{~d}$ \\
\hline 30 & $*$ & $*$ & $*$ & $\mathrm{NS}$ \\
\hline Interaction & Figure 1 & Figure 2 & Figure 3 & \\
\hline
\end{tabular}

$*=$ Significant at probability level of 5\% and NS = Non-Significant.

Mean values with different letter(s) are statistically and significantly different 


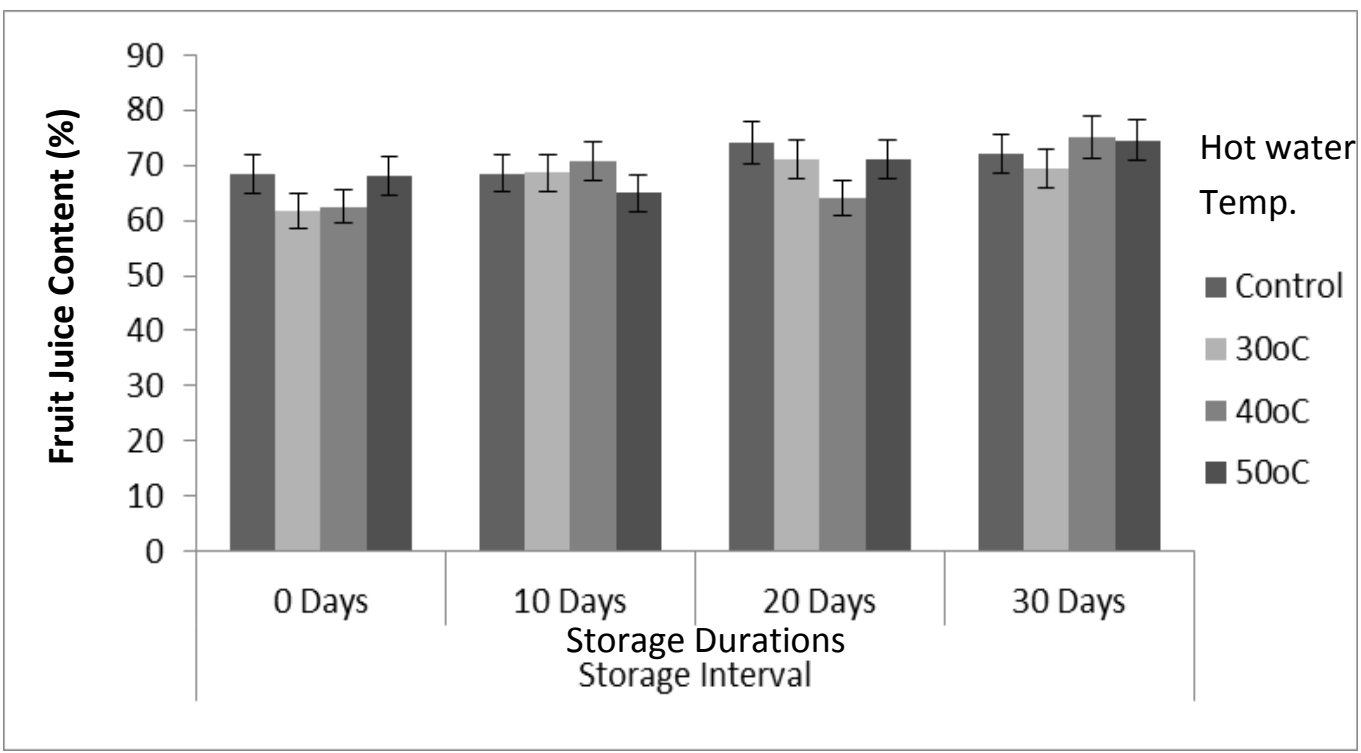

Figure 1. Effect of hot water treatments and storage durations on fruit juice content (\%) of peach

\section{Percent weight loss}

Table 1 shows the data observed for fruit weight loss. Its analysis of variance indicated that hot water treatment, storage intervals and their interaction had significant effect on fruit weight loss of peach. The mean table revealed that the maximum weight loss $(7.63 \%)$ was observed in fruits treated with hot water $\left(50^{\circ} \mathrm{C}\right)$, while minimum $(2.57 \%)$ was observed in fruits treated with $40^{\circ} \mathrm{C}$ water. As regarding the different storage duration, maximum weight loss $(10.41 \%)$ was recorded in fruits stored for 30 days. The minimum weight loss $(0.76 \%)$ was observed in fruits not stored. As referred to the mean values of interaction (Figure 2), maximum weight loss $(16.90 \%)$ was observed in fruits dipped in hot water $\left(50^{\circ} \mathrm{C}\right)$ and stored for 30 days, while the minimum was recorded in fruits left untreated and un-stored (Freshly harvested fruits). Weight loss was higher in un-treated and stored fruits while heat treated fruit at $40^{\circ} \mathrm{C}$ and the fruits left un-stored had the lowest loss in weight. It might be due to the fact that heat treatment delays ripening process. Furthermore, the proceeding of storage days increases the fruit weight loss. Similar results were observed by Candir et al. [10] who stated that peach fruits treated at $40-45^{\circ} \mathrm{C}$ gave lowest weight loss. Similarly Tareen et al. [11] observed that percent weight loss increased with increasing trend in all the treatments during storage time. 


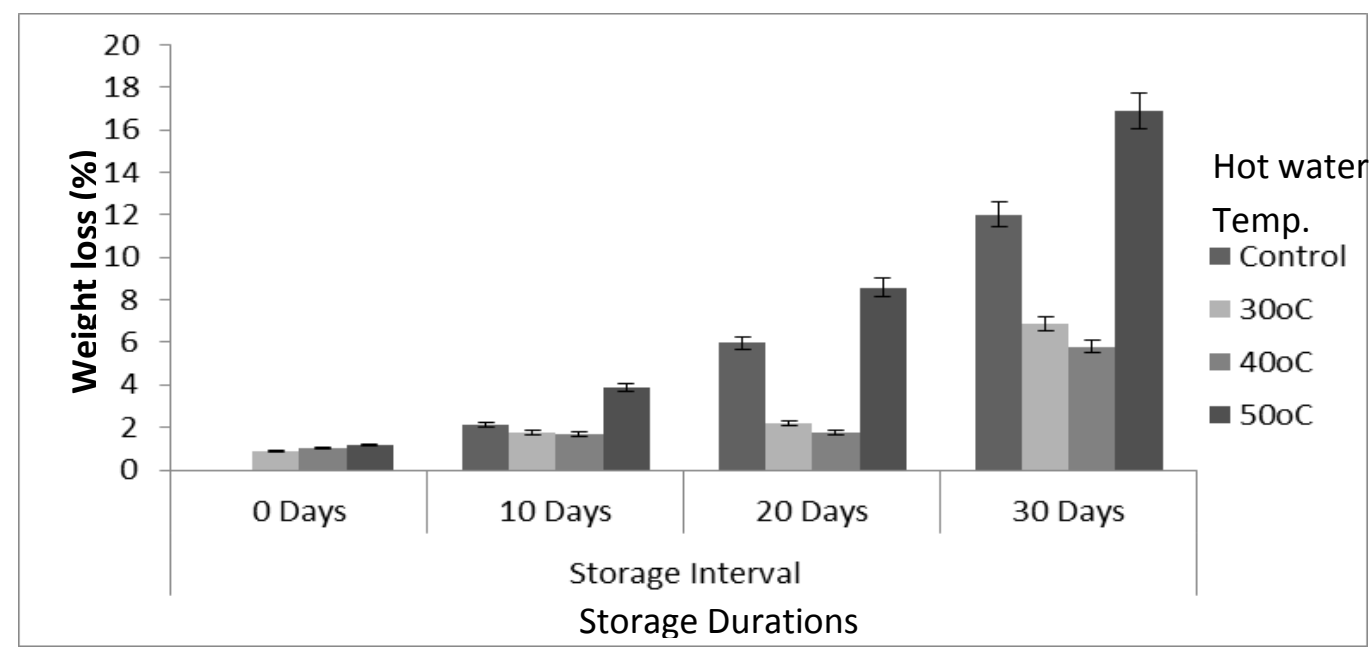

Figure 2. Effect of hot water treatments and storage durations on fruit juice content $(\%)$ of peach

\section{Disease incidence}

Results in Table 1 revealed significance difference with hot water treatment, storage interval and their interaction on disease incidence of peach. According to mean table, the maximum disease incidence $(49.17 \%)$ was observed in fruits treated with hot water at $50 \mathrm{oC}$, while minimum $(14.17 \%)$ was observed in fruits dipped in water having $40^{\circ} \mathrm{C}$ temperature. As regarding the different storage duration, maximum disease incidence $(47.50 \%)$ was recorded in fruits stored for 30 days. While minimum disease incidence $(0.00 \%)$ was observed in freshly harvested fruits. Data regarding the interaction (Figure 3), revealed that maximum disease incidence of $80.00 \%$ was observed in fruits dipped in $50^{\circ} \mathrm{C}$ water and stored for 30 days, while minimum was recorded in fruits left untreated and unstored. These results are in correspondence with Liu et al. [12] in peach fruits, that, when peach fruits treated with $40 \mathrm{oC}$ gave better result as compared to other treatments. Ghasemnezhad et al. [13] recorded that temperature above $47.5^{\circ} \mathrm{C}$ for 2-5 min resulted in fruits susceptible to heat damage and rind browning. Basal level of skin damage was observed in all heat treatments.

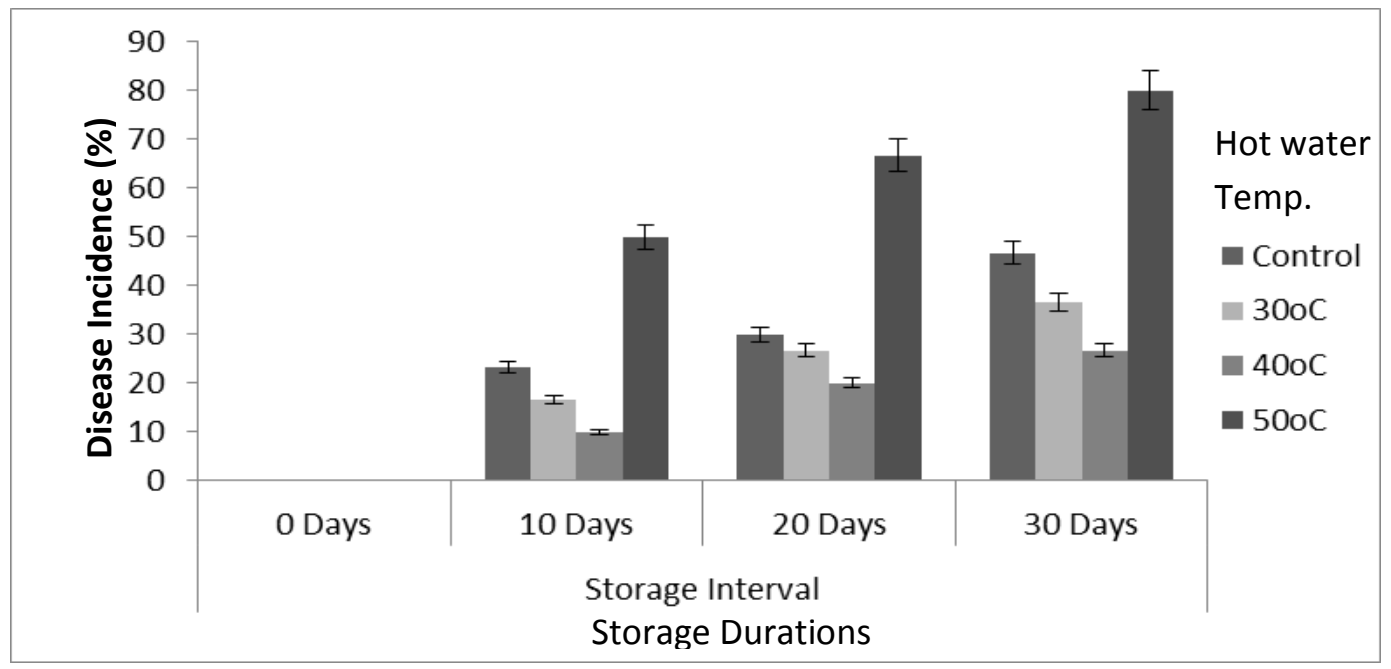

Figure 3. Effect of hot water treatments and storage durations on disease incidence (\%) of peach 


\section{Fruit firmness}

Significant difference of storage internal was noted with fruit firmness while it was recorded non-significant with interaction (Table 1).Maximum fruit firmness of 1.73 $\mathrm{kg} \mathrm{cm}^{-2}$ was observed in the fruits treated with $40^{\circ} \mathrm{C}$ water, while the minimum of 1.29 $\mathrm{kg} \mathrm{cm}$-2 was observed in untreated fruits .Results for storage intervals indicated maximum fruit firmness $\left(2.43 \mathrm{~kg} \mathrm{~cm}^{-2}\right)$ in freshly harvested fruits. Minimum fruit firmness value $\left(0.41 \mathrm{~kg} \mathrm{~cm}^{-2}\right)$ was recorded in freshly harvested fruits. Reason for such results might be because heat treatments delays to processes involved in ripening, due to which softening of the fruits is delayed. Similar results were recorded by Lurie [6] that peach fruits, when treated at $38^{\circ} \mathrm{C}$ or $40^{\circ} \mathrm{C}$ softened slower than control. Similar results were also observed previously that firmness of fruit decreased as the storage duration of fruit increased Zhou et al. [14].

\section{Fruit juice pH}

Data recorded for fruit juice $\mathrm{pH}$ is presented in Table 2. Its analysis of variance indicated that hot water treatment and storage intervals had a significant effect on fruit juice $\mathrm{pH}$ of peach, while their interaction had non-significant interaction. Mean table revealed that maximum fruit juice $\mathrm{pH}$ (3.69) was observed in the fruits treated with hot water of the temperature $50^{\circ} \mathrm{C}$, while minimum (3.54) was observed in fruits lefts untreated. As referred to storage intervals, the maximum fruit juice $\mathrm{pH}$ (3.91) was recorded in fruits stored for 30 days, whereas the $\mathrm{pH}$ (3.30) recorded in freshly harvested fruits was the minimum. In general, juice acidity of fruits had been found to decrease and $\mathrm{pH}$ to increase with storage duration. Similar results were also observed by Robertson et al. [15] who observed increased in fruit juice $\mathrm{pH}$ with increasing storage intervals as compared to control fruits. Increase in $\mathrm{pH}$ of tomatoes at room temperature with increased storage time was in agreement with the findings by Mohammed et al. [16].

Table 2. Fruit juice pH, total soluble solid(TSS), titratable acidity (T.A), TSS: TA ratio, ascorbic acid (A.A) and total sugarof peach fruits as affected by hot water dipping and storage intervals

\begin{tabular}{|l|c|c|c|c|c|c|}
\hline $\begin{array}{l}\text { Hot water } \\
\text { dipping }\left({ }^{\circ} \mathbf{C}\right)\end{array}$ & $\begin{array}{c}\text { Fruit juice } \\
\mathbf{p H}\end{array}$ & $\begin{array}{c}\text { TSS } \\
(\mathbf{0} \mathbf{B r i x})\end{array}$ & $\begin{array}{c}\text { T.A } \\
(\%)\end{array}$ & $\begin{array}{c}\text { TSS: TA } \\
\text { Ratio }\end{array}$ & $\begin{array}{c}\text { A.A } \\
\left(\mathbf{m g . 1 0 0} \mathbf{g}^{-1}\right)\end{array}$ & $\begin{array}{c}\text { Total sugars } \\
(\%)\end{array}$ \\
\hline Control & $3.54 \mathrm{~b}$ & $8.63 \mathrm{~d}$ & $0.45 \mathrm{a}$ & $19.50 \mathrm{~d}$ & $6.03 \mathrm{a}$ & $7.60 \mathrm{a}$ \\
\hline $30^{\circ} \mathrm{C}$ & $3.57 \mathrm{~b}$ & $8.89 \mathrm{c}$ & $0.40 \mathrm{~b}$ & $22.69 \mathrm{c}$ & $5.50 \mathrm{~b}$ & $6.17 \mathrm{~b}$ \\
\hline $40^{\circ} \mathrm{C}$ & $3.60 \mathrm{ab}$ & $10.08 \mathrm{~b}$ & $0.33 \mathrm{c}$ & $30.44 \mathrm{~b}$ & $5.07 \mathrm{c}$ & $5.88 \mathrm{c}$ \\
\hline $50^{\circ} \mathrm{C}$ & $3.69 \mathrm{a}$ & $11.49 \mathrm{a}$ & $0.30 \mathrm{~d}$ & $38.06 \mathrm{a}$ & $4.30 \mathrm{~d}$ & $5.60 \mathrm{~d}$ \\
\hline $\begin{array}{l}\text { Storage } \\
\text { Duration (days) }\end{array}$ & $3.30 \mathrm{~d}$ & $9.67 \mathrm{~b}$ & $0.40 \mathrm{a}$ & $25.52 \mathrm{c}$ & $5.45 \mathrm{a}$ & $6.53 \mathrm{a}$ \\
\hline 0 & $3.51 \mathrm{c}$ & $9.70 \mathrm{~b}$ & $0.38 \mathrm{ab}$ & $26.94 \mathrm{bc}$ & $5.34 \mathrm{ab}$ & $6.39 \mathrm{~b}$ \\
\hline 10 & $3.68 \mathrm{~b}$ & $9.86 \mathrm{a}$ & $0.37 \mathrm{bc}$ & $28.09 \mathrm{~b}$ & $5.10 \mathrm{~b}$ & $6.23 \mathrm{c}$ \\
\hline 20 & $3.91 \mathrm{a}$ & $9.86 \mathrm{a}$ & $0.34 \mathrm{c}$ & $30.14 \mathrm{a}$ & $5.02 \mathrm{~b}$ & $6.11 \mathrm{~d}$ \\
\hline 30 & $\mathrm{NS}$ & $*$ & $\mathrm{NS}$ & $\mathrm{NS}$ & $\mathrm{NS}$ & $*$ \\
\hline Interaction & Figure 4 & & & & Figure 5 \\
\hline
\end{tabular}

$*$ = Significant at probability level of $5 \%$ and NS = Non-Significant.

Mean values with different letter(s) are statistically and significantly different 


\section{Total soluble solids}

Data recorded for total soluble solid contents is presented in Table 2. Its data analysis indicated that hot water treatment, storage intervals and their interaction had a significant effect on total soluble solids of peach. According to mean table, maximum total soluble solid content $\left(11.49^{0}\right.$ Brix $)$ was observed in fruits treated with hot water of the temperature $50^{\circ} \mathrm{C}$ while minimum $(8.63$ ${ }^{\circ}$ Brix) was observed in freshly harvested. As regarding the storage durations, maximum total soluble content $\left(9.86^{\circ} \mathrm{Brix}\right)$ was found in fruits stored for 30 days. Minimum total soluble solid content (9.67) recorded in freshly harvested fruits. As referred to interactive effect (Figure 4), maximum total soluble solid content $\left(12.24{ }^{0}\right.$ Brix $)$ was observed in fruits dipped in $50^{\circ} \mathrm{C}$ water and stored for 30 days, while minimum was recorded in fruits left untreated and unstored. These results are in harmony with Ozdemir and Dundar [17] that an increase had been found in total soluble solid contents of orange fruit during storage. Shah et al. [18] mentioned that increase in soluble content of product may be due to solubilization of fruit constituents during storage.

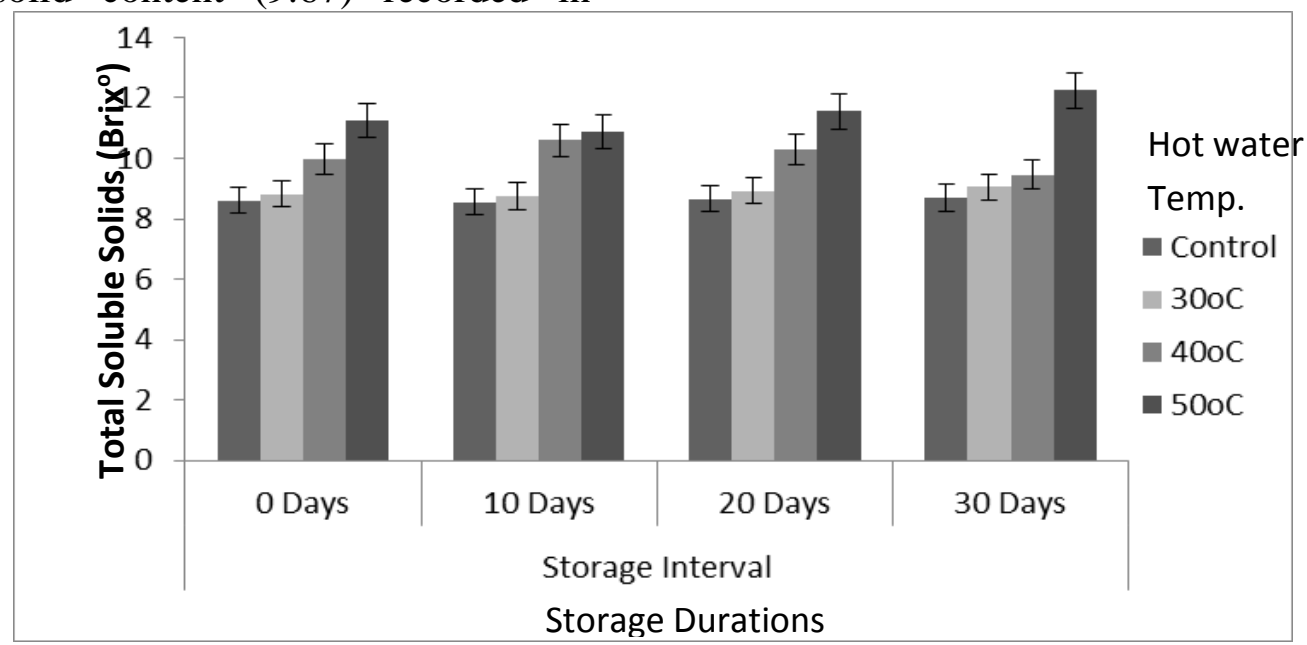

Figure 4. Effect of hot water treatments and storage durations on total soluble solids $\left(\mathrm{Brix}^{0}\right)$ of peach

\section{Titratable acidity}

Data recorded for titratable acidity content is presented in Table 2. Its analysis of variance indicated that hot water treatment and storage intervals had a significant effect while their interaction had a non-significant effect on titratable acidity of peach. Mean table revealed that maximum titratable acidity $(0.45 \%)$ was observed in freshly harvested fruits. Minimum titratable acidity (0.30) observed in fruits treated with hot water treatment of $50^{\circ} \mathrm{C}$. Regarding storage intervals, maximum titratable acidity $(0.40 \%)$ was recorded in fresh harvested fruits whereas minimum $(0.34 \%)$ was recorded in un-stored fruits. The results are in agreement with findings of Rapisarda et al. [19] who stated that a decrease in percent acidity during storage may occur due to the increase in maturity or ripening of the fruits. Moreover, this decrease might be due to breakdown of pectin to pectenic acid. Workneh et al. [20] found that there was a rapid decrease in TA of tomatoes as the storage days passed.

TSS: TA ratio

Table 2 presents the data recorded for TSS to TA ratio. Analysis of data indicated that hot water treatment and storage intervals had a significant effect but their interaction did not affect significantly sugar-acid ratio of peach. According to mean table, maximum 
sugar-acid ratio (38.06) was observed in fruits treated with hot water of temperature $50{ }^{\circ} \mathrm{C}$, while minimum sugar-acid ratio (19.50) was observed in controlled fruits. As regarding the storage durations, maximum sugar-acid ratio (30.14) was found in fruits stored for 30 days. The minimum sugar-acid ratio (25.52) was recorded in fresh harvested fruits. These results are in line with results of Rapisarda et al. [19] who noted an increase in the proportion of TSS/TA of oranges. Similarly, Khalil et al. [21] recorded increase in the TSS/Acid ratio for peaches.

\section{Ascorbic acid content}

Data recorded for ascorbic acid content is showed in Table 2. Analysis of data indicated that hot water treatment had a significant effect, but storage intervals and their interaction did not significantly affect the ascorbic acid content of peach. According to mean table, maximum ascorbic acid content $\left(6.03 \mathrm{mg}^{100 \mathrm{~g}^{-1}}\right.$ ) was observed in fruits receiving no water treatment. Minimum (4.30 mg $100 \mathrm{~g}^{-1}$ ) was observed in fruits dipped in water having $50^{\circ} \mathrm{C}$ temperature. Fruits are natural sources of ascorbic acids (vitamin C) and it is known that level of fruits decreases during ripening and processing. These results are in line with results of Yahia et al. [22] that level of ascorbic acid content was higher in control fruits as compared to the fruits which were treated with hot water. Kinh et al. [23] stated that ascorbic acid contents of apples were decreased during storage.

\section{Total sugar content}

Data recorded for total sugar content is given in Table 2. Data analysis showed that hot water treatment, storage intervals and their interaction had a significant effect on total sugars of peach. According to mean table, maximum total sugars value $(7.60 \%)$ was observed in the controlled fruits, while minimum total sugar $(5.60 \%)$ was observed in fruits treated with $50^{\circ} \mathrm{C}$ water. As regarding storage durations, maximum total sugar value $(6.53 \%)$ was found in un-stored fruits, while minimum total sugar value $(6.11 \%)$ was recorded in fruits stored at 30 days interval. As referred to mean values of interaction (Figure 5), maximum total sugar value $(8.06 \%)$ was observed in controlled and freshly harvested fruits, while minimum was recorded in fruits treated with $50^{\circ} \mathrm{C}$ water and stored at 30 days interval. These results are in correspondence with Aung et al. [24] who observed that total sugars were significantly higher in fruit not treated with hot water. Similar results were also observed by Khan et al. [9] that total sugars were higher in fresh sweet oranges and decreased with increasing duration of storage.

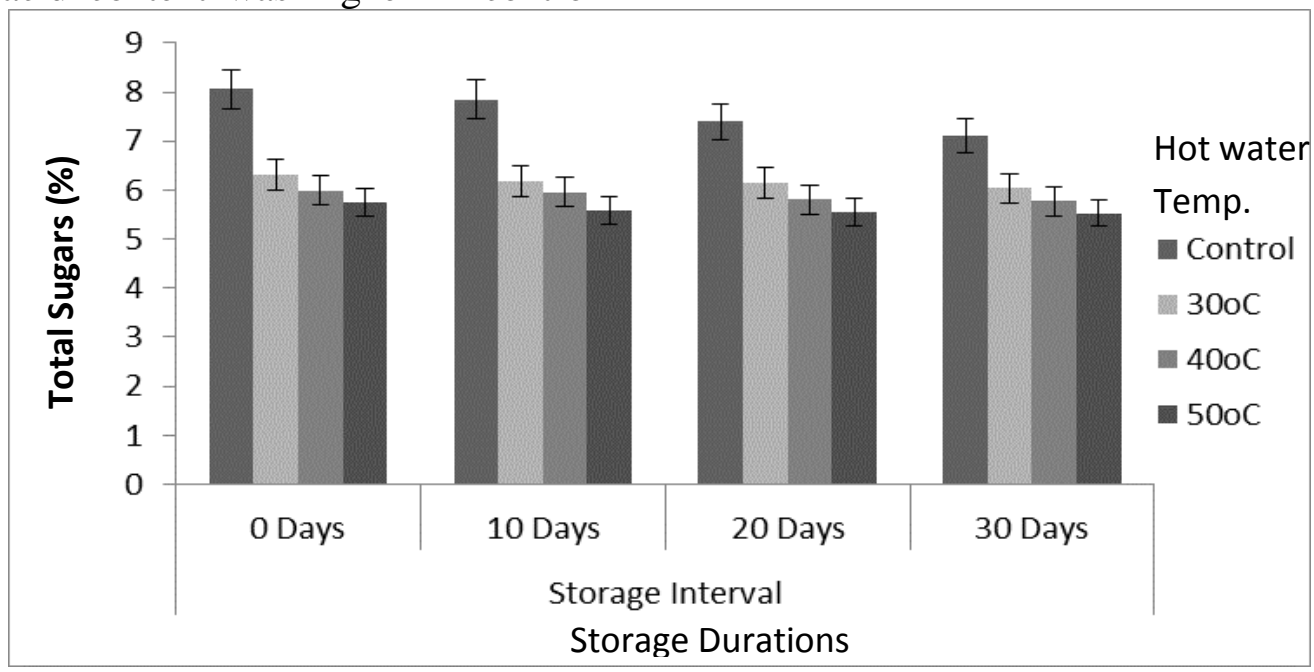

Figure 5. Effect of hot water treatments and storage durations on total sugars (\%) of peach 


\section{Conclusions and recommendations}

It was concluded that hot water treatment significantly affected all qualitative and quantitative parameters. The fruit dipping at $40^{\circ} \mathrm{C}$ showed best results for disease incidence, fruit firmness, fruit $\mathrm{pH}$. Storage duration up to 20 days was found to be the most effective.

Hence it is recommended that peaches should be treated with hot water at $40^{\circ} \mathrm{C}$ to increase its storage duration up to 20 days. Moreover, peaches should not be treated with hot water at $50^{\circ} \mathrm{C}$ and above as it showed adverse effects on most of qualitative and quantitative traits.

\section{Authors' contributions}

Conceived and designed the experiments: $M$ Sajid, Performed the Experiments: S Ullah \& I Ullah, Analyzed the Data: I Ullah, Z Ahmad \& F Bibi, Contributed reagents/ materials/ analysis tools: A Rab, MU Khan \& M Hussain, Wrote the paper: M Sajid \& I Ullah.

\section{Acknowledgement}

Above all I thank the Almighty Allah who is being with me and showers his blessings and grace towards me in all walks of my life. Words are not enough to thank my guide Dr. M. Sajid, Staff and faculty members, Department of Horticulture, The University of Agriculture, Peshawar, Pakistan. for their tremendous support, cooperation and selfless help extended by them during various stages of my work.

\section{References}

1. Ferguson B, Hldelorand R \& Hespendheild $\mathrm{G}$ (1987). All about growing fruits, berries and nuts. Ortho books San Francisco, CA :287.

2. Khattak MS, Malik MN \& Khan MA (2002). Guava propagation Via in Vitro Technique. Sarhad J Agric 18(2): 199202.

3. Louis HA, Jenner JF, Leesch JG \& Ryan FJ (2001). Postharvest quality/phytotoxicity of fresh commodities subjected to Mb Alternative Treatments USDA, ARS, Hort. Crops Res Lab

4. Wang CY (1998) Heat treatment affects postharvest quality of kale and collard but not of Brussels sprouts. Hort Science 33(5): 881-883.

5. Paull RE \& Chen NS (2000). Heat treatment and fruit ripening. Postharvest Biol \& Technol 21: 21-37.

6. Lurie S (1998). Review Postharvest heat treatments. Postharvest Biol \& Technol 14: 257-269.

7. Margosan DA, Smilanick JL, Simmons GF \& Henson DJ (1997). Combination of hot water and ethanol to control postharvest decay of peaches and nectarines. Plant Dis 81: 1405-1409.

8. AOAC (1990). Official Methods of Analysis, Association of Analytical Chemists. Ed. 16 ${ }^{\text {th }}$, Arlington Virginia, USA.

9. Khan GA, Rab A, Sajid M \& Salimullah (2007). Effect of heat and cold treatments on post-harvest quality of sweet orange cv. Blood red. Sarhad J Agric 23(1): 3946.

10. Candir L, Karabulut OA \& Bakyal N (2009). Integrated control of postharvest diseases of peaches with a yeast antagonist, hot water and modified atmosphere packaging. Crop Protection 23(5): 431-435.

11. Tareen MJ, Abbasi NA \& Hafiz IA (2011). Postharvest application of salicylic acid enhanced antioxidant enzyme activity and maintained quality of peach $c v$. 'Florida king'fruit during storage. Science Horti 142: 221228.

12. Liu J, Sui Y, Wisniewski M, Droby S, Tian S, Norelli J \& Hershkovitz V (2012). Effect of heat treatment on inhibition of Moniliniafructicola and induction of disease resistance in peach 
fruit. Postharvest Biol \& Technol 65: 61-68.

13. Ghasemnezhad M, Marsh K, Shilton R, Babalar M \& Woolf A (2008). Effect of hot water treatments on chilling injury and heat damage in 'satsuma' mandarins: Antioxidant enzymes and vacuolar ATPase, and pyrophosphatase. Postharvest Biol \& Technol 48: 364-371.

14. Zhou T, Xu S, Sun DW \& Wang Z (2001). Effects of heat treatment on postharvest quality of peaches. $J$ Food Engg 54: 17-22.

15. Robertson SA, Meredith FI, Horvatand RS \& Senter SD (1990). Effect of cold storage and maturity on the physical and chemical characteristics and volatile constituents of peaches cv Crest Haven. J Agric Food Chem 38: 620-624.

16. Mohammed M, Wilson LA \& Gomes PI (1999). Postharvest Sensory and physiochemical attributes of processing and non-processing tomato cultivars. $J$ Food Quality 22(2):167-182.

17. Ozdemir AE \& Dundar O (2001). Effect of different postharvest applications on storage of 'Valencia' oranges. Acta Hort 553: 561-564.

18. Shah WH, Sufi NA \& Zafar SI (1975). Studies on the storage stability of guava fruit juice. Pakistan J Science \& Ind Research 18(3-4): 179-183.
19. Rapisarda P, Bellomo SE \& Intelisano S (2001). Storage temperature effects on blood orange fruit quality. Agri. Food Chem. Washington D.C. American Chem Soc 49(7): 3230-3235.

20. Workneh TS, Osthoff G \& Steyn M (2012). Effects of preharvest treatment, disinfections, packaging and storage environment on quality of tomato. $J$ Food Science Technol 49(6): 685-694.

21. Khalil SA, Muhammad A, Roshan Z, Muhammad S, Ali M, Fazali W \& Muhammad F (2012). Influence of postharvest hot water dip treatment on quality of peach fruit (Prunuspersica). $J$ Med Plants Res 6(1): 108-113.

22. Yahia EM, Soto-Zamora G, Brecht JK \& Gardea A (2007). Postharvest hot air treatment effects on the antioxidant system in stored mature-green tomatoes. Postharvest Biol Technol 44: 107-115.

23. Kinh AE, Shearer H, Dunne CP \& Hoover DG (2001). Preparation and preservation of apple pulp with chemical preservatives and mild heat. J Food Prot 28(6): 111-114.

24. Aung LH, Obenland DM \& Houk LG (1998). Conditioning and heat treatments influence flavedo soluble sugars of lemon. J Hort Science Biotechol 73(3): 399-402. 